\section{E A Institute of \\ YK Business Administration \\ 光 \\ Karachi \\ Leadership and Ideas for Tomorrow}

Article 11

Volume 6 Issue 1 January-June 2011

$1-1-2011$

\title{
Back Matter of Volume 6 Number 1
}

Tufail A. Qureshi

Institute of Business Administration, Karachi, Pakistan

Follow this and additional works at: https://ir.iba.edu.pk/businessreview

Part of the Business Commons

(c) (i)

This work is licensed under a Creative Commons Attribution 4.0 International License.

\section{Recommended Citation}

Qureshi, T. A. (2011). Back Matter of Volume 6 Number 1. Business Review, 6(1), 153-154. Retrieved from https://doi.org/10.54784/1990-6587.1188

This article is brought to you by iRepository for open access under the Creative Commons Attribution 4.0 License and is available at https://ir.iba.edu.pk/businessreview/vol6/iss1/11. For more information, please contact irepository@iba.edu.pk. 


\title{
IBA \\ 米 \\ 米
}

\section{BUSINESS REVIEW}

\author{
Research Journal \\ of \\ The Institute of Business Administration \\ Karachi, Pakistan
}

\section{NOTE FOR CONTRIBUTORS}

This Journal is biannual publication of the Institute of Business Administration, Karachi, Pakistan. It is a multidisciplinary Journal covering wide range of issues in the area of business, social and management sciences, administration and governance, mathematics and computer studies, finance, economics, psychology, business ethics, logic, history of ideas, and philosophy of comparative religion.

\section{GUIDELINES FOR AUTHORS}

1. Manuscript should be submitted to the Editor, Business Review, Institute of Business Administration, University Road, Karachi, Pakistan.

2. Three copies of the manuscript should be submitted.

3. The text should be double spaced, on one side of the quarto paper allowing wide margins for referee's comments.

4. All illustrations, tables, etc., should be placed on separate sheets, included with each copy. Their placement should be indicated in the text.

5. Footnotes should be numbered consecutively throughout the text.

6. The first page of the manuscript should contain the following information: (i) title of the paper; (ii) the name(s) and institutional affiliation(s) of the authors(s); (iii) a footnote should give the name, postal address, telephone and fax number, and an email address of the authors. 
7. The second page must contain the title, an abstract not exceeding 300 words, a maximum of 5 key words or phrases and the appropriate JEL codes to be used for indexing purposes. The text will start on page number 3 .

8. Acknowledgements of all sorts should be included on the first page.

9. All mathematical derivations should be presented on a separate sheet (note to be published) to help the referees.

10. Manuscript should include only those references that are cited in the text. Authors are advised to follow American Psychological Association (APA) style of referencing.

11. All literary material, including books, journals and manuscript for review should be submitted in triplicate to the Editor, Business Review, Institute of Business Administration, University Road, Karachi, Pakistan.

12. It is assumed that the paper submitted is an original unpublished work and it has not already been published or submitted for publication elsewhere.

13. The opinion, ideas and evaluations expressed in the articles printed in the Business Review do not necessarily represent the views or polices of The Institute of Business Administration or the Editorial Board. They should be considered as representative examples of opinions and analysis now current in the academic field on various subjects of intellectual, educational and cultural interest.

14. After internal evaluation, the Editor will send the selected articles to the external referees or the consulting foreign editors for their evaluation. Selection of the referees will be the discretion of the Editor.

15. No article or part thereof should be reproduced in any form anywhere without the prior and written permission of the Editor, Business Review.

For advance electronic submission of the material:

businessreview@iba.edu.pk

tufail.qureshi@gmail.com

All enquiries should be addressed to the Editor, Business Review, Research Journal

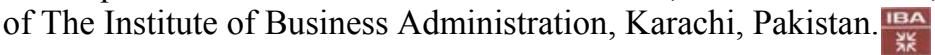

